\title{
Removal of sulphates from acid mine drainage using desilicated fly ash slag
}

\author{
F. Ntuli ${ }^{1}$, T. Falayi ${ }^{2} \&$ U. Thwanane ${ }^{1}$ \\ ${ }^{1}$ Department of Chemical Engineering, \\ University of Johannesburg, South Africa \\ ${ }^{2}$ Department of Civil Engineering Sciences, \\ University of Johannesburg, South Africa
}

\begin{abstract}
The removal of sulphates from acid mine drainage (AMD) using desilicated fly ash (DFA) was investigated. The effects of DFA solid loading, residence time and removal temperature were investigated. A $2 \%$ DFA solid loading gave the highest sulphate removal of $75 \%$ at a temperature and residence time of $35^{\circ} \mathrm{C}$ and $90 \mathrm{~min}$ respectively. The maximum adsorption capacity for DFA was found to be $147.06 \mathrm{mg} / \mathrm{g}$ DFA. The sorption mechanism followed the Langmuir isotherm and pseudo second order kinetics. The Gibbs free energy and enthalpy for the sorption was found to be 17.26 and $125.096 \mathrm{~J} / \mathrm{mol}$ respectively. This research showed that DFA was an attractive alternative adsorbent for sulphates in AMD.

Keywords: desilicated fly ash, adsorption, sulphates, isotherm.
\end{abstract}

\section{Introduction}

Sulphate contamination in water is prevalent in mining activities. Water effluent from gold mines and platinum mines have been shown to have a sulphate load of at least $2 \mathrm{~g} / \mathrm{L}[1,2]$. There are many problems which are associated with high sulphate content in water and these include laxative effects when concentration is above $500 \mathrm{mg} / \mathrm{L}$ and scaling effects [3]. Sulphate removal has traditionally been through use of membrane separation and by sulphate salt precipitation $[4,5]$. The major disadvantage of applying these technologies for the removal of sulphates from sulphate and acid rich effluents is the start-up and operational costs [6]. Fly ash (FA) has been shown to be a cheap alternative for the removal of sulphates from acid mine drainage (AMD) but the major disadvantage is the high fly ash 
solid loading [7] which results in reduced efficient mass transfer [8]. In this research desilicated fly ash (DFA), the residue from leaching of silica from FA was used as an adsorbent. The adsorption isotherm, kinetics and thermodynamic parameters of the sulphate adsorption using DFA was also investigated.

\section{Experimental}

\subsection{Materials}

Acid mine drainage was obtained from a local gold mine in the West Rand of South Africa. Ethanol, concentrated hydrochloric acid, sodium chloride, barium chloride, sodium sulphate and glycerol were supplied by Rochelle Chemicals. DFA was prepared by leaching of silica from FA using $3 \mathrm{M} \mathrm{KOH}, 500 \mathrm{rpm}$ agitation speed, $25 \mathrm{~L} / \mathrm{S}$ ratio, leaching temperature of $100^{\circ} \mathrm{C}$ for $6 \mathrm{~h}$ [9].

\subsection{Equipment}

Batch adsorption tests were carried out in conical flasks using a Thermostatic shaker set at various temperatures. Mineralogical analysis of DFA was done using a Rigaku Ultima IV difractometer. $\mathrm{pH}$ was measured using Metler Toledo dual meter (Sevenduo $\mathrm{pH} /$ conductivity meter with a Metler Toledo InLab Pro ISM pH electrode probe). A UV Visible spectrophotometer (PG Instruments T60) was used to assay for sulphate ions.

\subsection{Sulphate analysis}

The Environmental Protection Agency (EPA) method 375.4 was used to analyse for sulphates.

\subsection{Effect of DFA solid loading on adsorption of sulphates}

0.4-2.4 $\mathrm{g}$ of DFA was added to a separate $100 \mathrm{ml}$ solution of AMD. The solutions were agitated at $200 \mathrm{rpm}$ using a thermostatic shaker maintained at $25^{\circ} \mathrm{C}$ for 2 hours. After $2 \mathrm{~h}$ the agitation was stopped and the solution $\mathrm{pH}$ was measured. The solutions were then filtered using vacuum filtration. The filtrate was then analysed for sulphates.

\subsection{Effect of residence time and temperature on the adsorption of heavy metals}

4 solutions of $100 \mathrm{ml} \mathrm{AMD}$ with $2 \mathrm{~g}$ each of DFA were prepared. The solutions were agitated at $200 \mathrm{rpm}$ using a thermostatic shaker maintained at $25^{\circ} \mathrm{C}$ for 30 , 60,90 and $120 \mathrm{~min}$ respectively. At the end of each agitation time the solution $\mathrm{pH}$ was measured. The filtrate was then analysed for sulphates.

The above procedure was repeated at $35^{\circ} \mathrm{C}$ and $45^{\circ} \mathrm{C}$ to see the effect of temperature on the adsorption of sulphates. 


\section{Results and discussion}

\subsection{XRD characterisation of DFA}

Figure 1 shows the XRD diffractogram of FA and DFA.

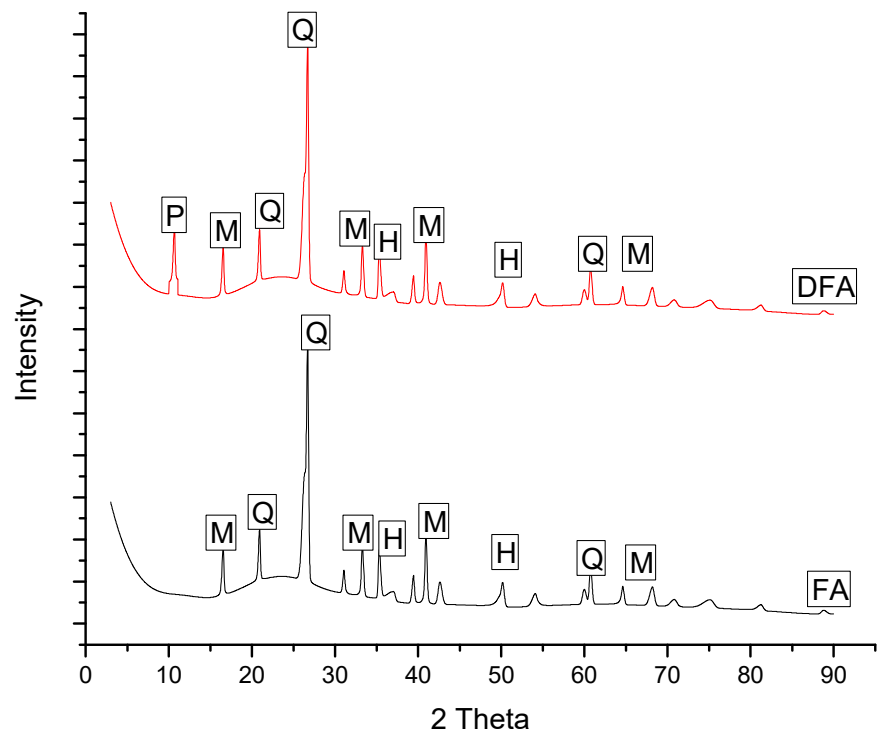

Figure 1: XRD diffractogram of FA and DFA $(\mathrm{M}=$ Mullite, $\mathrm{Q}=$ Quartz, $\mathrm{H}=$ Haematite, $\mathrm{P}=$ Phillipsite $\mathrm{K}$ ).

The XRD analysis of DFA showed no major differences with the parent FA except for the peak at $11^{\circ}$ which was identified as zeolite Phillipsite K. Phillipsite $\mathrm{K}$ constituted $25.8 \%$ of the crystalline phase of DFA. Therefore DFA is an impure zeolite. The Phillipsite is of the potassium type since silica extraction was done using $\mathrm{KOH}$.

\subsection{Effect of DFA solid loading}

Figure 2 shows the variation in sulphate removal with solid loading at $25^{\circ} \mathrm{C}$.

There was an increase in sulphate removal with an increase in solid loading because there were more adsorption sites available. The optimum effective solid mass loading of DFA for sulphates removal from AMD was found to be $2 \mathrm{~g} / 100 \mathrm{ml}$ AMD which resulted in 56.7\% removal. The removal at 2 and $2.4 \mathrm{~g} / 100 \mathrm{ml}$ AMD was found to be statistically insignificant and hence the solid loading of $2 \mathrm{~g} / 100 \mathrm{ml}$ AMD was used for subsequent experiments. Sulphate removal from waste water has also been shown to be $\mathrm{pH}$ dependent [10]. Figure 3 shows the variation of $\mathrm{pH}$ with solid loading. 


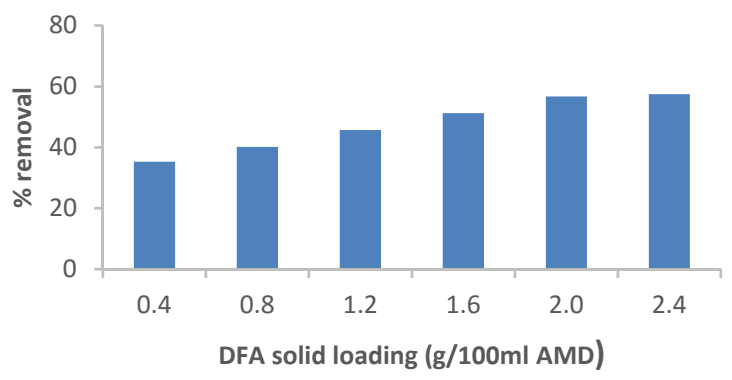

Figure 2: Variation in sulphate removal with DFA solid loading at $25^{\circ} \mathrm{C}$.

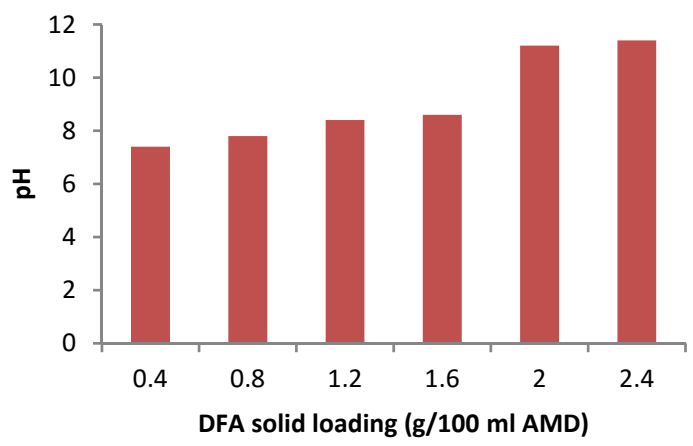

Figure 3: Variation of $\mathrm{pH}$ with solid loading.

Only the 2 and $2.4 \mathrm{~g} / 100 \mathrm{ml}$ AMD solid loading had the minimum required $\mathrm{pH}$ for effective sulphate removal [9] hence it was only at these solid loading that the sulphate removal was above $50 \%$. DFA is capable of removal of sulphates though it contains Phillipsite whose surface is negatively charged. This is probably due to a mix of adsorption and precipitation of sulphates since DFA has a $\mathrm{pH}$ of 12.28 [11].

\subsection{Effect of residence time}

Figure 4 shows the variation in sulphate removal with time.

There was an increase in \% removal with time up to $60 \mathrm{~min}$. This was due to the increased contact time between the adsorbent and adsorbate. The $\% \mathrm{SO}_{4}{ }^{2-}$ removal after 60 min remained stable signifying that equilibrium was reached at that stage. The slight decrease in \% removal after $60 \mathrm{~min}$ can be due to the slight desorption occurring after fast equilibration. 


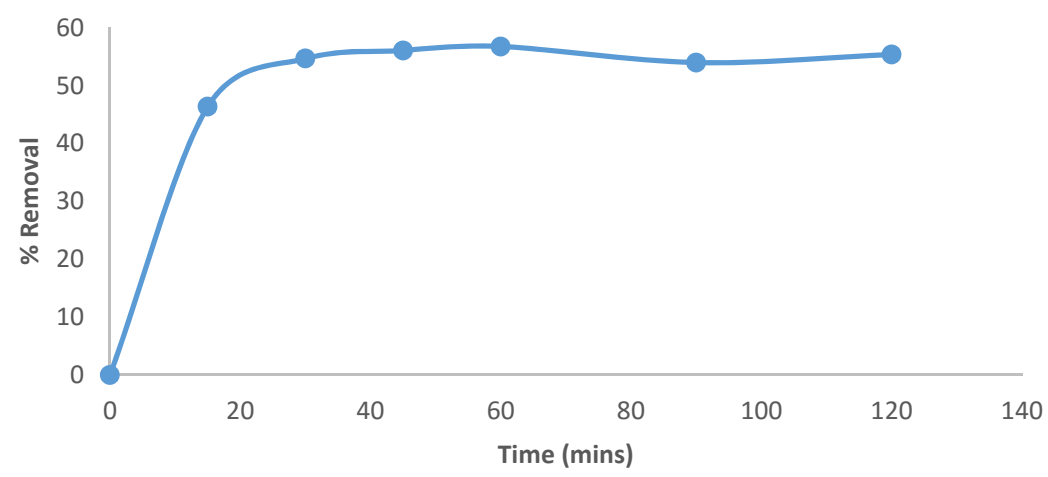

Figure 4: Variation in sulphate removal with time at $25^{\circ} \mathrm{C}$ at $2 \mathrm{~g} / 100 \mathrm{ml} \mathrm{AMD}$ solid loading.

\subsection{Effect of temperature}

Figure 5 shows the variation in metal removal with adsorption temperature.

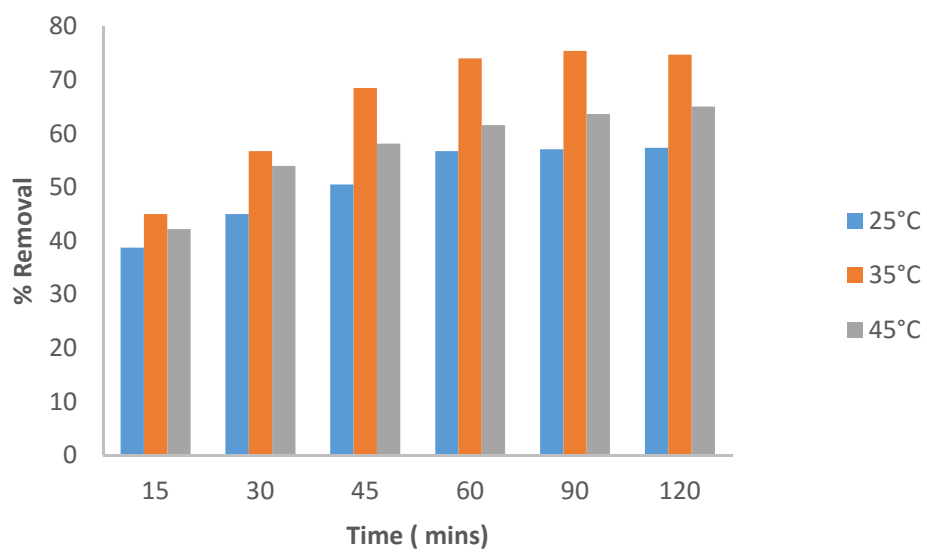

Figure 5: Variation in sulphate removal with adsorption temperature.

There was an increase in the sulphates removal with an increase in temperature from 25 to $35^{\circ} \mathrm{C}$ followed by a drop in sulphates removal at $45^{\circ} \mathrm{C}$. The first increase was due to more energy being supplied for the process since the adsorption process was endothermic. The decrease at $45^{\circ} \mathrm{C}$ was due to the increased solubility of sulphates with an increase in temperature [12]. 


\subsection{Adsorption isotherms}

The adsorption data at $35^{\circ} \mathrm{C}$ (highest removal) was then fitted to the Langmuir and Freundlich isotherms. Table 1 shows the Langmuir and Freundlich parameters.

Table 1: $\quad$ Langmuir and Freundlich parameters at $35^{\circ} \mathrm{C}$.

\begin{tabular}{ccc}
\hline Parameter & Langmuir & Freundlich \\
\hline$R^{2}$ & 0.9999 & 0.9989 \\
$n$ & & 30.98 \\
$R_{L}$ & 0.28 & \\
\hline
\end{tabular}

Both the Freundlich and the Langmuir isothem fit the adsorption of sulphates onto DFA as the corelation coefficient for for both isotherms was above 0.99 , however, the Langmuir isothem best fit the adsorption data as it had an equilibrium constant less than zero $\left(R_{L}\right)$ whilst the adsorption intensity $(n)$ for Freundlich was greater than $10[13,14]$.

\subsection{Adsorption kinetics}

The adsorption data at $35^{\circ} \mathrm{C}$ was then fitted to the pseudo first and second order kinetic equations. Figures 6 and 7 show the pseudo second order and first order plots respectively.

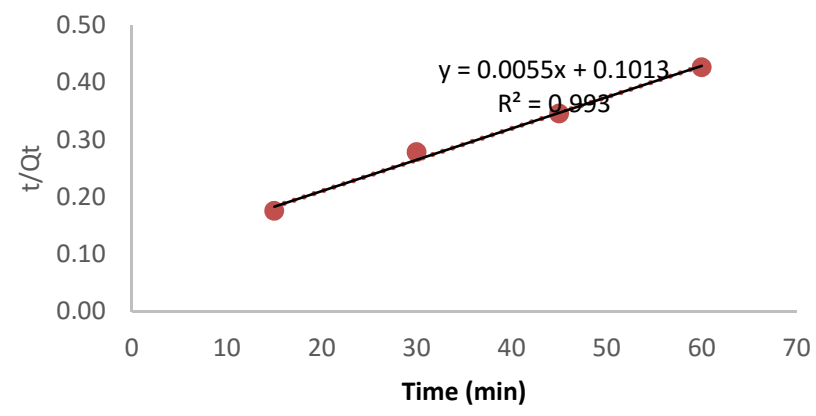

Figure 6: Pseudo second order plot.

The adsorption of sulphates onto DFA fitted the pseudo second order kinetic plot indicating a chemisorption process. This was further supported by the calculated equilibrium adsorption capacity for the pseudo first and second order kinetics were 318 and $181.8 \mathrm{mg} / \mathrm{g}$ respectively against an experimental value of $147.06 \mathrm{mg} / \mathrm{g}$. 


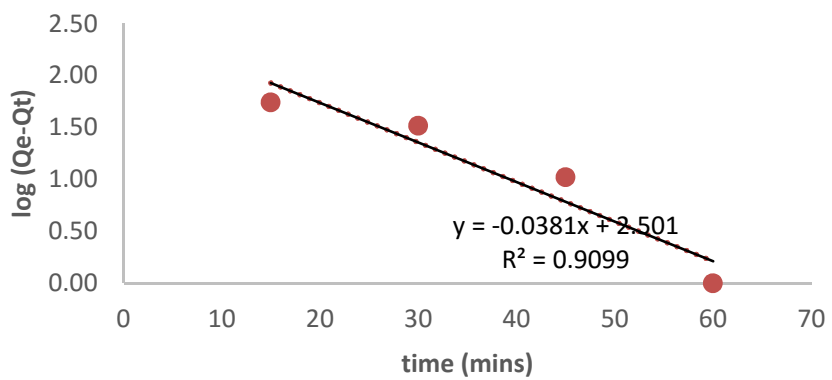

Figure 7: Pseudo second order plot.

\subsection{Adsorption thermodynamics}

Table 2 shows the thermodynamic parameters.

Table 2: Thermodynamic parameters of sulphate adsorption onto DFA.

\begin{tabular}{cc}
\hline Unit & Value \\
\hline$\Delta \mathrm{G}^{0}(\mathrm{~kJ} / \mathrm{mol})$ & -18.96 \\
$\Delta \mathrm{H}^{\mathrm{o}}(\mathrm{J} / \mathrm{mol})$ & 125.09 \\
$\Delta \mathrm{S}^{\mathrm{o}}(\mathrm{J} / \mathrm{mol})$ & 42.47 \\
\hline
\end{tabular}

The negative Gibbs free energy showed that the adsorption process was thermodynamically spontaneous, whilst a positive enthalpy value showed that the process was endothermic. A positive entropy value showed that there was high affinity for sulphates by DFA.

\section{Conclusion}

DFA can be used as an adsorbent for sulphates in AMD. A 2\% solid loading of DFA was found to be the optimum. The process followed Langmuir isotherm and was characterised by pseudo second order kinetics indicating a chemisorption mechanism. The process was thermodynamically spontaneous and was endothermic. The significant reduction in solid loading (2\%) as compared to $50 \%$ for FA represented a significant improvement in the process.

\section{Acknowledgements}

The authors would like to thank the University Research Council of the University of Johannesburg for their financial support. The authors are also thankful to the 
National Research Foundation of South Africa for providing a bursary for the student.

\section{References}

[1] Hobbs, P.J. and Cobbing, J.E., A hydrogeological assessment of acid mine drainage impacts in the West Rand Basin, Gauteng Province. Report CSIR/NRE/WR/ER/2007/0097/C. Council for Scientific and Industrial Research. Pretoria 2007.

[2] Maree, J.P. and Strydom, W.F., Biological sulphate removal in an up flow packed bed reactor. Water Res. 19, pp. 1101-1106, 1983.

[3] WHO 1996 Guidelines for drinking water quality. Geneva (2 vols.), 2nd edition.

[4] Adlem, C.J.L., Maree, J.P. and Pleiss, P.Du., Treatment of sulfate-rich mining effluents with the Barium Hydroxide process and recovery of valuable by-products. In: 4th International Mine Water association Congress, Ljubljana (Slovenia)-Portschach (Austria), September 1991, pp. 211-221, 1991.

[5] Bowell, R.J., Sulfate and salt minerals: the problem of treating mine waste. Mining and Environmental Management, pp. 11-14, 2000.

[6] De Smul, A., Dries, J., Goethals, L., Grootaerd, H. and Verstraete, W., High rate of microbial sulphate reduction in a mesophile ethanol fed expandedgranular sludge- blanket reactor. Appl. Microbiol. Biotechnol. 48, pp. 297303, 1997.

[7] Ntuli, F., Falayi, T. and Mabatho, M., A kinetic and thermodynamic study of sulphate removal from AMD using fly ash WIT Transactions on the Built Environment, Vol. 145, pp. 259-266, 2014.

[8] Nosrati, A., MacCarthy, J. and Addai-Mensah, J., Acid Leaching and Rheological Behaviour of Siliceous Goethite Ni laterite Ore: Effect of Solid Loading and Temperature. Proceedings of Chemeca, 2013.

[9] Falayi, T., Ntuli, F. and Okonta, F.N., Kinetic and thermodynamic parameters of silica leaching from Camden power station fly ash. Advances in Environmental and Agricultural Science, pp. 241-248.

[10] Madzivire, G., 2009. Removal of Sulfates from South African Mine Water Using Coal Fly Ash. Master's thesis University of the Western Cape, South Africa. 23(3), pp. 252-257.

[11] Falayi, T., Okonta, F.N. and Ntuli, F. The geotechnical and microstructural properties of desilicated fly ash lime stabilised expansive soil. Materials and Structures. DOI 10.1617/s 11527-016-0831-7

[12] Handbook of Chemistry and Physics (1997-1998). 78th ed. CRC press, pp. 4-87.

[13] Juang, R.S., Wu, F.C. and Tseng, R.L., Ability of activated clay for the adsorption of dyes from aqueous solutions: Environmental Technology, 18, p. 535 (1997).

[14] Tryball, R. E., Mass Transfers Operations, third ed., McGraw, New York (1980). 